\title{
Caminhos metodológicos de aproximação entre Bíblia e literatura a partir de Gérard Genette em obras machadianas
}

\author{
Weverton Castro
}

Faculdade Adventista da Amazônia

\section{César Martins de Souza}

Universidade Federal do Pará

\section{Resumo}

Os textos, considerados sagrados por diversos grupos religiosos, como a Bíblia, serviram de base para tramas e temas em diversas obras literárias. Assim, o presente artigo se lança na tarefa de dialogar sobre a metodologia para a compreensão das relações textuais a partir da teoria da transtextualidade de Gérard Genette na análise dos textos literários e bíblicos. Genette busca analisar a transcendência do texto e a relação que inclui o que vá além da unidade textual. $\mathrm{O}$ artigo se deterá em apresentar e definir a teoria da transtextualidade com suas divisões e subdivisões e, em seguida, analisar estes conceitos nas obras literárias de Machado de Assis, as quais dialogaram significativamente com os textos bíblicos.

Palavras-chave: Bíblia, Literatura, Transtextualidade, Gérard Genette, Machado de Assis

\section{Methodological paths of approximation between Bible and literature from Gérard Genette in Machado de Assis's works}

\begin{abstract}
The texts, considered sacred by several religious groups, such as the Bible, served as a basis for plots and themes in several literary works. Thus, the present article sets out to dialogue about the methodology for understanding textual relations based on Gérard Genette's theory of transtextuality in the analysis of literary and biblical texts. Genette seeks to analyze the transcendence of the text, and the relationship that includes what goes beyond the textual unity. The article will focus on presenting and defining the
\end{abstract}


theory of transtextuality with its divisions and subdivisions, and then analyzing these concepts in the literary works of Machado de Assis, which dialogued significantly with the biblical texts.

Keywords: Bible, Literature, Transtextuality, Gérard Genette, Machado de Assis

\section{Caminos metodológicos de aproximación entre la Biblia y la literatura desde Gérard Genette en las obras de Machado de Assis}

\section{Resumen}

Los textos, considerados sagrados por varios grupos religiosos, como la Biblia, sirvieron de base para tramas y temas en varias obras literarias. Así, el presente artículo establece un diálogo sobre la metodología para comprender las relaciones textuales basadas en la teoría de la transtextualidad de Gérard Genette en el análisis de textos literarios y bíblicos. Genette busca analizar la trascendencia del texto y la relación que incluye lo que va más allá de la unidad textual. El artículo se centrará en presentar y definir la teoría de la transtextualidad con sus divisiones y subdivisiones, y luego analizar estos conceptos en las obras literarias de Machado de Assis, que tuvieron un gran diálogo con los textos bíblicos.

Palabras clave: Biblia, Literatura, Transtextualidad, Gérard Genette, Machado de Assis

\section{Introdução}

A Bíblia, o livro sagrado do cristianismo, é considerada pelos praticantes desta religião como a revelação de Deus, não contendo apenas palavras humanas, mas verdades divinas, sendo elevada, portanto, pelos cristãos, acima de um livro comum, de modo que consideram, em contrapartida, os demais textos como seculares. Porém, os textos bíblicos não ficaram presos às paredes da religião. Eles se espalharam pela cultura e se infiltraram no mundo da arte, inclusive da literatura, onde encontraram um terreno fértil para novos olhares, leituras e interpretações, as quais, diga-se de passagem, se distanciaram, por vezes, da perspectiva doutrinária teológica.

Diante deste cenário, em que obras literárias se apropriaram dos textos bíblicos, um duplo preconceito surgiu na tentativa de erigir um muro de separação. Antônio Magalhães (2008), em seu texto intitulado A Bíblia na Crítica Literária, aponta que tanto os teólogos, com o desejo de restringir a leitura bíblica ao círculo religioso, quanto os críticos literários, que negaram o valor e a influência dos textos bíblicos, contribuíram para o distanciamento entre a Bíblia e a literatura.

Ao invés de continuar na tentativa de separação, diversos estudiosos se propuseram a estudar as relações entre Bíblia e Literatura (FRYE, 2004). 
Os resultados apontam que a literatura encontra nos textos bíblicos uma fonte importante de inspiração para a construção de novos textos, ao passo que a Bíblia encontra na literatura uma forma de preservação e divulgação de suas tramas e temas, a partir de novas formas, alcançando novos lugares não tocados pela teologia.

Porém, surge agora uma questão crucial para o investigador que deseja avançar nesta aproximação Bíblia/literatura: como identificar a presença do texto bíblico nas obras literárias? Aqui então se encontra a questão central que motivou o presente artigo, buscando problematizar a construção de uma ferramenta metodológica que possibilite compreender as relações entre os textos. O método que apresentaremos daqui em diante baseia-se na teoria da transtextualidade de Gérard Genette, à qual dedicaremos uma primeira parte deste trabalho para defini-la; em seguida, numa segunda parte, a analisaremos em obras literárias de Machado de Assis, muitas das quais dialogaram grandemente com os textos bíblicos.

\section{Literatura machadiana em diálogo com a Bíblia}

Da perspectiva cronológica, empréstimos de personagens e temas bíblicos por obras literárias acompanham toda a história da Bíblia. Prova disso são os inúmeros livros pseudoepígrafos, tanto do Antigo quanto do Novo Testamento, que elaboravam narrativas fantasiosas a partir do conteúdo extraído da Bíblia. A multiplicação de tais obras, que se identificavam como escritas por personagens bíblicos e com uma linguagem semelhante à da Bíblia, levou os líderes da igreja cristã primitiva a esclarecer a questão dos livros que deveriam ser considerados sagrados (canônicos) e aqueles que não o eram, devendo, pois, serem considerados falsos (pseudoepígrafos) (GEISLER; NIX, 1997, p. 88).

Livros pseudoepígrafos do Novo Testamento compõem uma lista extensa. Existem diversos evangelhos que trazem detalhes da vida de Jesus que não são contados pelos evangelhos canônicos, como o Evangelho de Tomé (século I) - que fala de supostos milagres que Jesus teria realizado em sua infância. Existem também diversos Atos, Epístolas e Apocalipses, que constroem novas narrativas a partir de personagens e temas extraídos da Bíblia (cf. GEISLER; NIX, 1997).

Mesmo a teologia clássica reconhece o valor histórico destes livros, por refletirem aspectos importantes da cultura que cercava o cristianismo primitivo. Tais obras também têm ganhado espaço no meio acadêmico através de diversos estudos literários em torno deles, como no estudo desenvolvido 
por Gaspari \& Braga (2008).

Em sua dissertação de mestrado, Silva (2015) analisa Machado de Assis como um leitor da Bíblia, trazendo um tema complexo e muitas vezes conflituoso, que é a exploração de temáticas e narrativas bíblicas em obras literárias:

O diálogo entre a Bíblia e a Literatura é muito conflituoso e complexo. Muitos estudiosos acham que são dois mundos separados, pois não veem que as obras literárias mundiais trazem, muitas delas, uma dimensão religiosa, ora por paráfrase ora por paródia. Assim, tanto a Bíblia como a literatura universal, que vai buscá-la como fonte de inspiração, questionam a mesma coisa, têm o homem como centro de sua produção, levando o leitor a refletir acerca da complexidade da existência humana (SILVA, 2015, p. 20).

Para a autora é a complexidade humana o elo que leva muitos literatos a beberem em fontes bíblicas, se utilizando de recursos literários como a paródia ou a comédia, pois a Bíblia seria marcada por literariedade e por elementos filosóficos que possibilitam problematizar de modo denso os dramas da humanidade. Silva (2015, p. 43) analisa também que Machado de Assis quando jovem, apesar de demonstrar ser um cristão ingênuo e simples, já trazia as "sementes da rebeldia" e mesmo que em sua vida adulta tenha manifestado "perder a fé" sempre manteve conexão entre suas obras e a Bíblia.

Em um estudo que se tornou um clássico sobre o tema, Bressane aponta as conexões entre Machado de Assis e o cristianismo, ao discutir sua formação católica desde a infância (BRESSANE, 1978). No mesmo sentido, Fernando Brum (2009) também ressalta em sua análise um forte diálogo com temas cristãos, sobretudo católicos, nas obras de Machado de Assis, trazendo assim diversos recursos literários para construir narrativas que se encontram com temáticas e narrativas presentes na Bíblia.

Damasceno (2010) afirma que muitas obras de Machado de Assis trazem paródias das palavras de Jesus nos evangelhos, para construir críticas sociais às situações que vivenciava naquele momento, mas que permitem pensarmos sobre outros tempos, pois sua abordagem não perde a atualidade, devido ao fato de que mergulha em temas bíblicos para adentrar na complexidade da existência da humanidade e nos problemas que esta vivencia.

Salma Ferraz acredita que Machado se utiliza da liberdade para reinventar a Bíblia em narrativas literárias, chegando até mesmo a trazer comicidade em suas produções que dialogam com um campo sagrado. 
A autora advoga em favor da liberdade da criação literária e também das diferentes leituras que podem ser construídas sobre as obras inspiradas nos textos sagrados do cristianismo (FERRAZ, 2013).

Assim, é notório que as relações de aproximação entre a literatura e a Bíblia podem ser estudadas a partir de diferentes possibilidades teóricas, de forma que no presente texto se construirá a análise a partir da teoria de Gérard Genette, denominada de transtextualidade ou teoria do palimpsesto.

\section{Relações transtextuais de Genette}

Diversas tipologias de intertextualidade são devedoras das relevantes observações de Gérard Genette. Em termos gerais, ele tratava os diálogos entre textos como "relações transtextuais": a transcendência do texto, tudo o que põe em relação, ainda que "secreta, um texto com outros e que inclui qualquer relação que vá além da unidade textual de análise. (GENETTE, 2010). Sua teoria visava identificar um texto "antigo" que se esconde sob o "novo". Na introdução de sua obra Palimpsestos (2010), o autor esclarece a razão do título nos termos a seguir:

Um palimpsesto é um pergaminho cuja primeira inscrição foi raspada para se traçar outra, que não a esconde de fato, de modo que se pode lê-la por transparência, o antigo sob o novo. Assim, no sentido figurado, entenderemos por palimpsestos (mais literalmente: hipertextos) todas as obras derivadas de uma obra anterior, por transformação ou por imitação. Dessa literatura de segunda mão, que se escreve através da leitura, o lugar e a ação no campo literário geralmente, e lamentavelmente, não são reconhecidos. Tentamos aqui explorar esse território. (GENETTE, 2010, p. 7)

Para Genette, "um texto pode sempre ler um outro, e assim por diante até o fim dos textos", sendo assim, "quem ler por último lerá melhor". Para ele, a transtextualidade, ou transcendência textual do texto, seria "tudo que o coloca em relação, manifesta ou secreta, com outros textos.” (GENETTE, 2010, p. 07, 13). Embora dê uma atenção especial à hipertextualidade, Genette cita uma lista de cinco tipos de relações transtextuais: Intertextualidade, Paratextualidade, Metatextualidade, Hipertextualidade e Arquitextualidade.

\section{Relações transtextuais: Intertextualidade}

A primeira categoria de transtextualidade, denominada de 
Intertextualidade, deriva da teoria de Julia Kristeva (1969), porém, é retomada por Genette de um modo mais restrito. Segundo ele, a intertextualidade acontece quando há a "presença efetiva de um texto em um outro." (GENETTE, 2010, p. 14). Nesta categoria estão incluídas as citações explícitas (com aspas, com ou sem referência precisa) ou menos explícitas como no caso do plágio, o qual seria um empréstimo ilegal e não declarado, mas ainda literal. Uma forma ainda menos explícita e menos literal é a alusão, a qual aconteceria quando há "um enunciado cuja compreensão plena supõe a percepção de uma relação entre ele e um outro, ao qual necessariamente uma de suas inflexões remete" (GENETTE, 2010, p. 14).

\section{Relações transtextuais: Paratextualidade}

O segundo tipo de relação transtextual apresentado por Genette é denominado por ele como paratextualidade. Trata-se de uma relação menos explícita e que se relaciona com diversos aparatos textuais, chamados por Genette de "acessórios”, tais como: título, subtítulo, intertítulos, posfácios, posfácios, advertências, prólogos, notas marginais, de rodapé, de fim de texto, epígrafes, ilustrações, orelha, capa, etc. (GENETTE, 2010, p. 15)

Koch, Bentes e Cavalcante (2012, p. 132) chamam a atenção para a questão delicada envolvendo o paratexto no que concerne à delimitação do que pode, ou não, ser considerado um intertexto, visto que os títulos, os subtítulos, as notas e as ilustrações compõem o próprio texto "e só configurarão uma situação de intertextualidade se tiverem sido extraídas de outros textos, para que se estabeleça a interseção."

\section{Relações transtextuais: Metatextualidade}

A metatextualidade é apresentada de forma bem sucinta por Genette como uma relação de "comentário" que une um texto-fonte a outros que dele tratam. Tal relação pode ocorrer sem que haja necessariamente citação ou nomeação do mesmo; trata-se de uma espécie de alusão silenciosa. "É, por excelência, a relação crítica" (GENETTE, 2010, p. 17).

Vale destacar a ressalva de Genette de que os tipos de transtextualidade não são mutuamente excludentes e que alguns são essenciais para a definição do outro (GENETTE, 2010, p. 14). Note-se que o prefácio e o posfácio de uma obra, que seriam manifestação de paratextualidade, também se constituiriam como um metatexto, ou seja, como uma espécie de comentário crítico sobre a obra, que, por sua vez, está repleta de citações, de referências 
e de alusões.

Após sua definição breve do conceito, o próprio Genette assume (talvez se incluindo no grupo) que não se tem dado toda a atenção que merece o estudo da relação metatextual (GENETTE, 2010, p. 17).

\section{Relações transtextuais: Hipertextualidade}

O quarto tipo de transtextualidade, batizada por Genette como hipertextualidade, é a categoria que ganha maior destaque em sua obra e se diferencia das demais categorias em um ponto específico: o hipertexto se descreve por uma relação de derivação.

Enquanto que as outras são apresentadas como figurantes, a hipertextualidade recebe uma atenção maior do autor. $\mathrm{Na}$ obra ela é colocada no quarto lugar, na categorização de cinco tipos, porém, é apresentada por último. Genette nos diz: "entendo por hipertextualidade toda relação que une um texto B (que chamarei hipertexto) a um texto anterior A (que, naturalmente, chamarei hipotexto)" (GENETTE, 2010, p. 18). Genette amplia seu debate ao declarar que "todas as obras são hipertextuais", embora algumas manifestam mais claramente sua dívida a obras anteriores. (GENETTE, 2010, p. 24).

Genette classifica o processo de derivação hipertextual em dois grandes grupos: Transformação e Imitação. Estas podem ocorrer de três formas: lúdica, satírica e séria. O quadro abaixo resume a teoria de Genette.

\section{Quadro 1. Práticas hipertextuais}

\begin{tabular}{|cc:c:c|}
\hline REGIME/RELAÇÃO & LÚDICO & SATÍRICO & SÉRIO \\
\hline Transformação & Paródia & Travestimento & Transposição \\
\hline Imitação & Pastiche & Charge & Forjação \\
\hline
\end{tabular}

Fonte: (GENETTE, 2010, p. 42)

As linhas pontilhadas, preservadas do texto original, representam as fronteiras maleáveis entre os tipos de hipertextualidade, evidenciando a interface entre eles. Isso não "exclui absolutamente a possibilidade de práticas mistas” (GENETTE, 2010, p. 43).

Genette admite que sua divisão não é absoluta e considera a possibilidade da existência entre o lúdico e o satírico do irônico, sem entrar em mais detalhes de como ele funcionaria. Ou também a possibilidade de 
entre o satírico e o sério existir o polêmico. Entre o lúdico e o sério, o bumorístico. França \& Vieira (2008) acreditam que o conceito de hipertextualidade engloba as demais formas de transtextualidades:

Se, substancialmente, a hipertextualidade é definida a partir da ideia de que um texto B não existiria tal como ele é sem que anteriormente existisse um texto $A$, podemos dizer que qualquer um dos outros quatro tipos de transtextualidade, no final das contas, também pode ser visto como um processo hipertextual. (FRANÇA; VIEIRA, 2008, p. 53)

Embora possamos concordar que a definição de Genette sobre a hipertextualidade é mais genérica e abrangente que as demais, não podemos minimizar a importância das diferentes formas de manifestações das relações transtextuais ressaltadas por cada categoria desenvolvida pelo autor. Porém, para a compreensão do papel da hipertextualidade, como declaram acertadamente França e Vieira (2008), é necessário ir além da simples preocupação em classificar e anotar os indícios da presença de um texto em outro. É importante que ela ultrapasse as linhas e entrelinhas e "tome como seu objetivo principal verificar até que ponto, tal como propõe Genette, uma obra B não existiria da forma que existe sem a existência prévia da obra A." (FRANÇA; VIEIRA, 2008, p. 56)

\section{Relações transtextuais: Arquitextualidade}

O quinto tipo de relação transtextual é a arquitextualidade. Segundo Genette, esta é a forma mais abstrata e mais implícita. Em suas palavras, esta seria "uma relação completamente silenciosa que, no máximo, articula apenas uma menção paratextual.” (GENET'TE, 2010, p. 17). Dois grupos são citados pelo autor como exemplo. O primeiro seria o titular, uma espécie de classificação da obra, como em Poesias, Ensaios..., ou infratitular, como Romance, Narrativa, Poemas..) que acompanham o título, na capa. Estes gêneros seriam o aspecto arquitextual, e funcionariam como uma espécie de status do texto. Apesar de estarem sujeitos a críticas, pois o leitor pode rejeitar a classificação indicada na obra, esta percepção do gênero da obra é importante pois “em larga medida orienta e determina o 'horizonte de expectativa' do leitor e, portanto, da leitura da obra.” (GENETTE, 2010, p. 17)

A arquitextualidade funcionaria como uma espécie de filiação do texto a outras categorias, como o tipo de discursos, modo de enunciação, o gênero, etc. Esta relação raramente é explícita, pois "em geral, um texto não informa o tipo de gênero, ou de discurso, a que pertence.” (KOCH; 
BENTES; CAVALCANTE, 2012, p. 132)

De certa forma, o fenômeno da arquitextualidade não seria exatamente uma intertextualidade, isto é, uma relação entre textos, mas antes se configuraria como um enquadramento de um texto em outras categorias maiores. A não ser se considerarmos as próprias categorias como metatextos que se impõem sobre os textos classificados.

\section{Relações transtextuais na literatura machadiana}

Joaquim Maria Machado de Assis, nascido na cidade do Rio de Janeiro em 1839, ainda em vida foi considerado o principal escritor brasileiro. Sua vasta produção se diversifica entre os mais diversos estilos e gêneros: romance, poesia, críticas de teatro, tradução, conto e crônica. Em seus escritos é possível perceber como a Bíblia lhe serviu como fonte para a criação de temas, tramas e personagens.

Schwarz (1977) analisa que Machado de Assis surge em um cenário brasileiro marcado por obscurantismo escravocrata que confronta a humanidade com as inumanidades do cotidiano. Para Schwarz, em um contexto em que a ciência era vista como fantasia e o obscurantismo ideológico chegava ao ponto de defender interesses escravocratas como sendo os legitimamente nacionais, surge Machado de Assis lançando um olhar crítico e analítico para pensar a realidade nacional e expandir dela para outros temas complexos da humanidade, através de sua pena literária.

Merquior (1996) destaca, portanto, a forte presença de elementos filosóficos na obra de Machado de Assis provocando um diálogo entre os elementos da sociedade brasileira trazidos presentes na literatura com as vozes da literatura ocidental que chegam a sair de seu tempo, o século XIX, para atravessar temporalidades posteriores.

\section{Intertextualidade em Machado de Assis}

A Intertextualidade restrita de Genette (2010, p. 14), a qual se refere à "presença efetiva de um texto em um outro" através da citação direta (por meio de aspas, negrito, sublinhado), plágio (meio ilegal) ou alusão (forma menos explícita), é usada por Machado de Assis em diferentes obras.

Eugênio Vinci de Moraes (2013, p. 40) analisa diversas citações de outras obras na obra $O$ Alienista de Machado de Assis. Ao se referir ao texto A Comédia de Dante Alighieri, Moraes declara que “as alusões a Dante são inúmeras na obra de Machado de Assis. Aparecem em todos os gêneros - 
poesia, crítica, crônicas, contos e romances -, da década de 1870 até seu último romance, Memorial de Aires." Moraes destaca os versos de Dante citados por Machado de Assis no fim do capítulo $\mathrm{V}$ de $O$ Alienista, extraídos dos dois primeiros do canto XXXIII, penúltimo do Inferno: "La bocca sollevò dal fiero pasto / Quel peccatore [...]".

Machado de Assis altera o segundo verso, o termo peccatore é substituído por seccatore. A mudança sutil da troca de "P" por "S" (ASSIS, 2015b, p.244) é defendida por Moraes como uma demonstração da desenvoltura de Machado com a língua italiana, além de um conhecimento profundo da obra citada, a Comédia.

Machado faz diversas alusões (relação de co-presença implícita) e citações (relação de co-presença explícita) da obra O Homem da Multidão, de Edgar Allan Poe, em seu conto intitulado Só!. Logo no início da obra Machado declara: "Um grande escritor, Edgar Poe, relata, em um de seus admiráveis contos, a corrida noturna de um desconhecido pelas ruas de Londres, à medida que se despovoam, com o visível intento de nunca ficar só." (ASSIS, 2015b, p. 179)

Enquanto que no conto de Poe, o "homem da multidão" enlouquece diante da aglomeração urbana, fruto da revolução industrial, no conto machadiano, recheado de ironia, o protagonista fica a ponto de enlouquecer com a solidão. A partir deste exemplo percebemos como, apesar de existir uma ligação entre os textos de Machado e Poe, ambos caminham em direção opostas quanto ao desfecho da trama. Assim, percebemos que Machado dialoga com outros textos, mas sua genialidade está na capacidade de recriar tradições, dando-lhes um toque particular.

\section{Paratextualidade em Machado de Assis}

Um autor que é bastante estudado em diálogo com os textos machadianos é Shakespeare. Helen Caldwell (2008, p. 20) diz ter encontrado 255 referências a Shakespeare na obra de Machado em inúmeras citações, paródias e menções a personagens das peças do dramaturgo inglês. Eugênio Gomes (1958) argumenta que Machado tinha preferência por certas peças, que são citadas com mais frequência em suas obras, como Hamlet, Otelo, Macbeth e Romeu e Julieta. Gomes (1958, p. 15) faz um levantamento das diferentes ocasiões nas quais Machado cita Shakespeare e defende que Hamlet foi uma das obras que mais influenciou o autor.

Desta obra, uma cena em especial que foi aproveitada por Machado de 
Assis é a conhecida cena do cemitério. Ela introduz o quinto ato de Hamlet com dois coveiros que aparecem trabalhando, cantando e fazendo piadas sobre a morte e a eternidade. Enquanto isso, Hamlet e Horácio filosofam sobre a transitoriedade da vida. Ao descobrir que a cova está sendo preparada para sua amada Ofélia, morta afogada num riacho, Hamlet se revela a todos e entra em uma briga com Laertes, irmão da amada. No fim, atendendo ao clamor da rainha, Hamlet se retira, prometendo que a disputa ainda não havia terminado.

Em 3 de junho de 1894, Machado de Assis publica na obra Páginas Recolbidas (2015b) uma paródia desta cena shakespeariana. A crônica deixa evidente sua apropriação de Hamlet já a partir de seu título: A cena do cemitério. A alusão fica mais evidente no segundo parágrafo da crônica, no qual o narrador cita o livro e o autor que lhe inspiraram o texto: "Sonhei que era Hamlet; trazia a mesma capa negra, as meias, o gibão e os calções da mesma cor. Tinha a própria alma do príncipe da Dinamarca. Até aí nada houve que me assustasse. Também não me aterrou ver, ao pé de mim, vestido de Horácio, o meu fiel criado José" (ASSIS, 2015b, p. 611).

Neste caso, o título da obra se enquadra perfeitamente na categoria de relação transtextual denominada por Genette de Paratextualidade, onde os aparatos textuais, denominados de "acessórios" (título, subtítulo, intertítulos, posfácios, posfácios, advertências, prólogos, notas marginais, de rodapé, de fim de texto, epígrafes...) conectam o texto B ao texto A (GENETTE, 2010, p. 15).

Machado também utiliza o recurso de notas explicativas em suas obras, as quais evocam textos anteriores ao dele. Tal fenômeno pode ser visto na introdução de sua obra Memórias Póstumas de Brás Cubas, na qual Machado dirige uma longa explicação ao leitor apresentando vários adjetivos de sua obra: “Trata-se, na verdade, de uma obra difusa, na qual eu, Brás Cubas, se adotei a forma livre de um Sterne, ou de um Xavier de Maistre, não sei se lhe meti algumas rabugens de pessimismo. Pode ser. Obra de finado" (ASSIS, 2015a, p. 599).

\section{Metatextualidade em Machado de Assis}

Classificada como a categoria silenciosa, que designa a relação que "une um texto a outros dos quais ele fala, através de alusões e diálogo velados" (GENETTE, 2010), a Metatextualidade aparece em diversas obras machadianas.

No romance Quincas Borba (2015a), Machado narra a trajetória de Rubião, professor que se torna rico de uma hora para outra ao receber 
uma herança deixada pelo filósofo Quincas Borba, criador de uma filosofia chamada Humanitismo. Após receber a herança, Rubião deslumbra-se com a nova vida e acaba traído por um casal de amigos, que rouba sua fortuna. No final da vida, pobre e doente, ele relembra um ensinamento de Quincas Borba, apresentado no capítulo VI sobre duas tribos famintas diante de um campo de batatas, suficientes apenas para alimentar um dos grupos. Neste contexto, a tribo mais forte precisa derrotar a mais fraca para sobreviver. Então, Quincas Borba finaliza: "Ao vencido, ódio ou compaixão; ao vencedor, as batatas" (ASSIS, 2015a, p. 741).

A filosofia presente em Quincas Borba, denominada Humanitismo, é uma reverberação da teoria da seleção natural, lançada por Charles Darwin entre 1842 e 1844, a qual está baseada na sobrevivência dos mais aptos e enxerga a guerra como forma de seleção da espécie, sintetizada na declaração: “Ao vencedor as batatas!" (ASSIS, 2015a, p. 741) Tal alusão crítica machadiana a Charles Darwin e a sua obra Evolução da Espécies pode enquadrar-se ao que Genette denominou de metatextualidade.

Machado também cita a obra de Darwin em seu conto Capitulo dos Chapéus (1883). Quando o marido de Mariana defende seu interesse pelo estudo do chapéu, ele questiona sua esposa: "Você nunca leu Laplace? Desde Laplace e a Mecânica celeste até Darwin e o seu curioso livro das Minhocas, e, entretanto, não se lembraram ainda de parar diante do chapéu e estudá-lo por todos os lados". (ASSIS, 2015b, p. 367)

Um tipo de relação metatextual interessante ocorre no romance Memorial de Aires (2015a), onde Machado cita logo no prefácio outra obra de sua própria autoria, Esaú e Jacó (2015a): "Quem me leu Esaú e Jacó talvez reconheça estas palavras do prefácio: 'Nos lazeres do ofício escrevia o Memorial, que, apesar das páginas mortas ou escuras, apenas daria (e talvez dê) para matar o tempo da barca de Petrópolis"” (ASSIS, 2015a, p. 1197).

A partir deste exemplo é interessante notar como um autor pode estabelecer relações metatextuais não somente com textos de outros autores, mas com seus próprios textos anteriormente elaborados.

\section{Hipertextualidade em Machado de Assis}

Genette definia a Hipertextualidade como "toda relação que une um texto B (que chamarei hipertexto) a um texto anterior A (que, naturalmente, chamarei hipotexto)" (GENETTE, 2010, p. 18). ele classifica o processo de derivação hipertextual em dois grandes grupos: Transformação e Imitação, que 
podem ocorrer de três formas: lúdica, satírica e séria. (GENETTE, 2010, p. 42)

$O$ fenômeno da transformação, conforme designado por Genette para se referir à interação hipertextual entre um texto $\mathrm{B}$ e um texto $\mathrm{A}$, pode ser visto no conto machadiano intitulado O sermão do Diabo. Machado de Assis recria o Sermão da Montanha, conforme consta no capítulo 5 do Evangelho de Mateus, invertendo os preletores. Ao passo que na Bíblia os ensinos são proferidos por Jesus de cima do monte da Oliveiras, no conto machadiano é o Diabo que, do alto do Corcovado, dirige-se aos seus discípulos (ASSIS, 2015b, p. 609, 610).

Embora as relações hipertextuais apontem para o aspecto de derivação de um texto a partir de outro, o que leva Ferraz (2012) a afirmar que não existe "nada novo", ao mesmo tempo, a conexão não significa uma repetição fiel do contexto original. No caso do conto A Igreja do Diabo, a derivação existe por conta da estrutura escolhida pelo autor de forma proposital, mas o restante é completamente invertido. É como se o leitor olhasse para o antigo expresso no novo, mas subvertido completamente de seu sentido original. O segundo escolhe conscientemente se erguer sobre a plataforma do primeiro, porém, justamente para destruí-lo. E embora paradoxal, o velho é conservado no novo através da destruição. É o fenômeno denominado por Késsia Oliveira de "reescritas desviantes" e "traições necessárias" (OLIVEIRA, 2016, p. 11).

Na obra Esaú e Jacó, através da boca do personagem Aires, Machado transforma um texto bíblico em outro, a partir da junção de outros textos: "No princípio era o amor, e o amor se fez carne". (ASSIS, 2015a, p. 1069). Neste verso citado por Machado, encontram-se pelos menos, três passagens bíblicas unidas para originar a nova versão bíblica machadiana: "No princípio era o verbo, e o verbo estava com Deus, e o verbo era Deus." (João 1:1. In: Bíblia Sagrada, 1999); "E o verbo se fez carne e habitou entre nós." (João 1:14. In: Bíblia Sagrada, 1999); “O amor jamais acaba.” (I Coríntios 13:8. In: Bíblia Sagrada, 1999).

\section{Arquitextualidade em Machado de Assis}

Embora as classificações arquitextuais de Genette (como o tipo de discursos, modo de enunciação, o gênero) não sejam feitas necessariamente pelo autor da obra, Machado filia seus textos a gêneros literários préestabelecidos.

Na Advertência de sua obra Papéis Avulsos, além do termo Advertência já o incluir na categoria de Paratextualidade, há também o elemento Arquitextual 
em sua sugestão de classificação:

Quanto ao gênero deles, não sei que diga que não seja inútil. O livro está nas mãos do leitor. Direi somente, que se há aqui páginas que parecem meros contos, e outras que o não são, defendo-me das segundas com dizer que os leitores das outras podem achar nelas algum interesse, e das primeiras defendome com São João e Diderot. O evangelista, descrevendo a famosa besta apocalíptica, acrescentava (XVII, 9): "E aqui há sentido, que tem sabedoria." Menos a sabedoria, cubro-me com aquela palavra. Quanto a Diderot, ninguém ignora que ele, não só escrevia contos, e alguns deliciosos, mas até aconselhava a um amigo que os escrevesse também. E eis a razão do enciclopedista: é que quando se faz um conto, o espírito fica alegre, o tempo escoa-se, e o conto da vida acaba, sem a gente dar por isso. (ASSIS, 2015b, p. 230)

Por ser de caráter taxonômico, a categorização que Machado faz de sua obra como conto, enquadra-se no que Genette chama de Arquitextualidade.

\section{Esaú e Jacó: relações transtextuais e paratextuais com a Bíblia}

Depois de olharmos de forma geral a presença da Bíblia em diversas obras machadianas, voltaremos nosso olhar para uma em específico: o livro Esaú e Jacó. Esta obra tem como protagonistas dois irmãos gêmeos, Pedro e Paulo, filhos de Natividade e Santos. Desde o nascimento ambos se tornam rivais em tudo. $\mathrm{Na}$ fase adulta as diferenças se acentuam ao se apaixonarem por Flora, a qual morre por não conseguir decidir qual dos irmãos realmente amava. Embora a obra não seja de cunho religioso, dentro dela encontramos diversas conexões com a Bíblia.

Como já vimos, Gérard Genette (2001) chama de paratexto um conjunto de unidades que adquirem funções significativas ao se tornarem parte do texto literário. Constituem essas unidades, além de sumário, prefácio, agradecimentos, dedicatória, referências e título, as epígrafes, consideradas como elementos independentes do texto literário.

Ao exemplificar a importância da paratextualidade para a compreensão do texto, Genette (2001) cita o caso de Ulisses, de Joyce. Em sua prépublicação, essa obra dispunha de títulos de capítulos que evocavam a relação de cada um deles com um episódio da Odisseia. Porém, lamenta Genette, na publicação, Joyce retira esses intertítulos, os quais seriam "de uma significação fundamental" (GENET'TE, 2001, p. 10).

De igual forma, o título do romance machadiano é a primeira porta que nos possibilita adentrar a obra a partir de suas referências a outras obras. 
As três palavras escolhidas por Machado para nomear seu romance, Esaú e Jacó, são inegavelmente uma referência a dois personagens bíblicos famosos do Antigo Testamento.

Este fato, por si só, já evidencia o diálogo que o romance se propõe a fazer com a Bíblia, ainda que ela não esteja no centro da trama. Nesse direção, podemos ir mais além e arriscar uma pergunta de difícil resposta unânime: por que Machado escolheu o nome de dois personagens bíblicos para o título deste livro?

Em primeiro lugar, engana-se quem pensa que os nomes escolhidos para o título são os mesmos para os personagens. Os protagonistas Pedro e Paulo têm seus nomes retirados do Novo Testamento. Na introdução do romance, Machado explica que o romance foi escrito pelo Conselheiro Aires, que, ao morrer, deixara "sete cadernos manuscritos, rijamente encapados em papelão". Em tinta encarnada, estão numerados de I a VI, tendo o sétimo o título de "Último" (ASSIS, 1904, p. 1046). Este foi transitoriamente chamado de "Ab Ovo" até receber o nome definitivo de Esaú e Jacó.

Tal foi a razão de se publicar somente a narrativa. Quanto ao título, foram lembrados vários, em que o assunto se pudesse resumir, Ab ovo, por exemplo, apesar do latim; venceu, porém, a idéia de lhe dar estes dois nomes que o próprio Aires citou uma vez: ESAÚ E JACÓ. (ASSIS, 2015a, p. 1046)

A pista dada na Advertência da obra é que existe uma relação entre o título Esaú e Jacó e a expressão latina ab ovo, que significa "desde o ovo". No primeiro capítulo tal relação fica mais evidente ao ser explorado o tema do conflito desde o nascimento entre os dois irmãos.

E não foi sem grande espanto que lhe ouviu perguntar se os meninos tinham brigado antes de nascer.

- Brigado?

- Brigado, sim, senhora.

- Antes de nascer?

- Sim, senhora, pergunto se não teriam brigado no ventre de sua mãe; não se lembra? (ASSIS, 2015a, p. 1049)

Desta forma, o tema do conflito entre irmãos desde o nascimento é o primeiro fio de ligação entre o romance machadiano e a Bíblia, tema este que dá origem ao título da obra e se torna a tônica estruturante de toda a obra.

O capítulo XLVII, intitulado S. MATEUS, IV, 1-10, é outro exemplo 
da forma como Machado se utilizou do elemento paratextual para conectar propositalmente sua obra aos textos bíblicos. Este capítulo apresenta a vitória do partido liberal sobre os conservadores e o abatimento de Batista diante da derrota. Ao introduzir este capítulo Machado explicita: "Se há muito riso quando um partido sobe, também há muita lágrima do outro que desce, e do riso e da lágrima se faz o primeiro dia da situação, como nos Gênesis. Venhamos ao evangelista que serve de título ao capítulo" (ASSIS, 2015a, p. 1103).

A partir deste elemento paratextual, Machado nitidamente recorre à Bíblia para apresentar a derrota do personagem Batista, objetivando comparálo a João Batista, o pregador do deserto que batizou Jesus Cristo. (Mt 3.1-4. In: Bíblia Sagrada, 1999)

Uma razão para Machado escolher o personagem bíblico para referenciar o Batista de seu romance é que ambos compartilham de um fim trágico. Ao passo que o Batista machadiano é derrotado na política, João Batista é apresentado na narrativa bíblica como vítima de acordos políticos que o levaram a perder a vida.

No capítulo XIV de Mateus, é relatada a festa de aniversário de Herodes, na qual a filha de Herodias, sua esposa, encantou o governador. Em um momento de empolgação ele promete que daria a ela qualquer coisa que lhe pedisse. Influenciada por sua mãe, ela pede a cabeça de João Batista em um prato. (Mt 14.9-11. In: Bíblia Sagrada, 1999)

Conectando-se novamente ao texto bíblico, ainda no capítulo XLVII do romance machadiano o tema da promessa conecta os personagens Batista.

Neste ponto passou-lhe um frio pela espinha. Justamente nessa ocasião apareceu Flora. O pai abraçou-a com amor, e perguntou-lhe se queria ir para alguma província, sendo ele presidente.

- Mas os conservadores não caíram?

- Caíram, sim, mas supõe que...

- Ah! não, papai!

- Não, por quê?

— Não desejo sair do Rio de Janeiro. (ASSIS, 2015a, p. 1105)

Porém, a conexão que Machado objetiva fazer no capítulo em questão gira em torno do tema da tentação. Em Mateus capítulo IV, dos versos 1 ao 10 é narrada a cena da tentação de Jesus no deserto, após ter jejuado por 40 dias. Após resistir a três investidas de Satanás, Jesus conclui a batalha citando 
um texto que se encontra no Antigo Testamento.

Então, Jesus lhe ordenou: Retira-te, Satanás, porque está escrito:

Ao Senhor, teu Deus, adorarás, e só a ele darás culto.

Com isto, o deixou o diabo, e eis que vieram anjos e o serviram. (Mt 4.10-11.

In: Bíblia Sagrada, 1999)

O texto citado por Jesus no Evangelho de Mateus encontra-se no livro de Deuteronômio no Antigo Testamento: “O SENHOR, teu Deus, temerás, a ele servirás, e, pelo seu nome, jurarás.” (Dt 6.13. In: Bíblia Sagrada, 1999)

Machado passa do recurso da paratextualidade e avança para a intertextualidade, fazendo uma citação direta do texto de Mateus em sua narrativa da cena de Batista:

Talvez o Rio de Janeiro para ela fosse Botafogo, e propriamente a casa de Natividade. O pai não apurou as causas da recusa; supô-las políticas, e achou novas forças para resistir às tentações de D. Cláudia: "Vai-te, Satanás; porque escrito está: Ao Senhor teu Deus adorarás, e a ele servirás.” E seguiu-se como na Escritura: "Então o deixou o Diabo; e eis que chegaram os anjos e o serviram." Os anjos foram só um, que valia por muitos; e o pai lhe disse beijando-a carinhosamente:

- Muito bem, muito bem, minha filha. (ASSIS, 2015a, p. 1105)

Neste exemplo encontramos de forma emblemática a dinâmica dos diálogos e entrecruzamentos dos textos. O Evangelho de Mateus recorre ao livro de Deuteronômio e o aplica a outro contexto, conferindo-lhe novos significados, ao passo que Machado busca no texto de Mateus inspiração para a construção de sua trama, fazendo, de certa forma, em seu romance o que Jesus fez no evangelho. Ambos usam um texto do passado para a construção de novas ideias, sem negar a dívida, porém, sem se tornarem meros repetidores, antes reconstroem o novo a partir do velho.

Além do título da obra, os nomes dos personagens estabelecem relações transtextuais do romance machadiano com a Bíblia. A partir deles é possível conectar o romance tanto com o Antigo quanto com o Novo Testamento.

\section{Esaú e Jacó, Antigo Testamento}

O primeiro livro da Bíblia, Gênesis, é dividido por diversos estudiosos em duas grandes seções: I. A origem da raça humana (capítulos 1 ao 11) e II. Origem do povo Judeu (capítulos 12 ao 50) (MATHEWS, 1996). A narrativa dos irmãos gêmeos Esaú e Jacó faz parte da seção do surgimento dos judeus 
a partir de seus patriarcas: Abraão, Isaque e Jacó. No capítulo 25 o autor do Gênesis descreve o conflito entre os dois filhos gêmeos de Isaque desde o nascimento (Gn 25:21-23. In: Bíblia Sagrada, 1999). O texto bíblico aprofunda a partir de então os conflitos entre os irmãos que, apesar de gêmeos, eram antagônicos em vários aspectos, tanto físicos quanto emocionais (Gn 25:2528. In: Bíblia Sagrada, 1999).

Com o desenvolvimento dos irmãos, e das diferenças entre ambos, o objeto central de disputa entre eles se torna o direito da primogenitura. Jacó, o irmão mais novo, cria uma estratégia para consegui-la, ele se aproveita da fome do irmão mais velho e troca o direito da primogenitura por um prato de comida (Gn 25:29-33. In: Bíblia Sagrada, 1999).

O comentário desta passagem em questão, contido na Bíblia de Estudo Almeida da Sociedade Bíblica Brasileira (1999), afirma que o primogênito ou filho mais velho tinha vários privilégios que o colocavam acima dos demais irmãos. Em particular, cabia a ele a primazia depois do pai e também uma porção dupla da herança familiar.

Para confirmar o direito à primogenitura, em complô com sua mãe, Rebeca, Jacó se disfarça de Esaú e recebe a benção de seu pai Isaque, o qual, por causa da visão fraca, não reconheceu o impostor. Daí então Jacó é forçado a fugir de casa por causa da ira que tomou conta de seu irmão Esaú.

No romance Esaú e Jacó, o enredo central é construído em torno dos dois irmãos gêmeos, Pedro e Paulo, os quais, à semelhança da narrativa bíblica, brigavam desde o ventre materno. A história inicia com a ida de Perpétua e Natividade ao Morro do Castelo para consultar a cabocla Bárbara. Sabendo de suas famosas profecias, Natividade desejava saber da cabocla como seria o futuro de seus filhos. Segundo Bárbara:

Serão grandes, oh! Grandes! Deus há de dar-lhes muitos benefícios. Eles hão de subir, subir... Brigaram no ventre de sua mãe, que tem? Cá fora também se briga. Seus filhos serão gloriosos. É só o que lhe digo. Quanto à qualidade da glória, coisas futuras! (ASSIS, 2015a, p. 1049)

Em uma cena, na qual se encontram Santos, Plácido e Aires, a questão do nascimento e briga dos meninos surge no meio do debate. Aires, buscando apresentar uma possível explicação para o acontecido, declara que "Esaú e Jacó brigaram no seio materno, isso é verdade. Conhece-se a causa do conflito. Quanto a outros, dado que briguem também, tudo está em saber a 
causa do conflito" (ASSIS, 1904, p. 1065). Nitidamente existe uma conexão entre os gêmeos do romance machadiano com os gêmeos bíblicos por conta da suposta luta no ventre da mãe.

Um outro aspecto, ainda que secundário, que nos permite conectar as duas narrativas, Bíblia-Machado, é o fato de que em ambas o nascimento dos gêmeos não era esperado pelos pais. Na Bíblia, Isaque ora a Deus para que ajude sua esposa, Rebeca, a qual não podia ter filhos por ser estéril (Gênesis 25:21, In: Bíblia Sagrada, 1999). No romance, Santos é pego desprevenido pela idade da esposa, a qual engravida aos trinta anos de idade. Segundo Santos, "aos trinta anos não era cedo nem tarde; era imprevisto. Santos sentiu, mais que ela, o prazer da vida nova. Eis aí vinha a realidade do sonho de dez anos, uma criatura tirada da coxa de Abraão" (ASSIS, 2015a, p. 1055).

O próprio nome de Abraão, citado por Santos, é uma referência ao patriarca, avô dos gêmeos Esaú e Jacó. Abraão, assim como Santos, também é pego desprevenido por conta da gravidez de sua esposa Sara, a qual concebeu “depois de velha" (Gênesis 18:12 In: Bíblia Sagrada, 1999).

O fato de os irmãos serem gêmeos, à semelhança da Bíblia, é usado de forma paradoxal por Machado, pois existem semelhanças e oposições entre eles. No contexto do nascimento dos meninos, havia expectativas diferentes nos pais, "Natividade queria um filho, Santos uma filha" (ASSIS, 1904, p. 1057), nasceram-lhes, porém, dois meninos idênticos: "No dia sete de Abril de 1870 veio à luz um par de carões tão iguais, que antes pareciam sombra um do outro, se não era simplesmente impressão do olho, que via dobrado" (ASSIS, 2015a, p. 1057).

Machado se refere à semelhança dos meninos como o ver "dobrado". As semelhanças entre os irmãos continuam durante toda a vida deles, os quais mesmo "aos sete anos eram duas obras-primas, ou antes uma só em dois volumes" (ASSIS, 1904, p. 1070).

Depois de grandes, "era natural que, assim bonitos, iguais, elegantes, dados à vida e ao passeio, à conversação e à dança, finalmente herdeiros, era natural que mais de uma menina gostasse deles." (ASSIS, 1904, p. 1082), porém, uma era moça que atraía a atenção dos irmãos, Flora.

No desenrolar do romance, a figura de Flora funciona como um catalizador, onde as diferenças entre os gêmeos desaparecem através do amor pela mesma mulher. A trama amorosa se desenrola em torno de Flora para saber qual dos dois ela escolheria. Porém, como escolher um, se os dois são 
o mesmo para ela? Confusa, e sem escolher qual dos dois ela preferia, Flora morre sem anunciar sua decisão. No enterro da amada, a figura da sombra retorna novamente, porém, em um aspecto enigmático (ASSIS, 2015a, p. 1181)

A semelhança entre os irmãos causa dificuldades, principalmente para a mulher amada por ambos, Flora. O capítulo CVI, cujo título já aponta para uma certa demência, Ambos Quais?, contém os últimos momentos de vida da moça, a qual falece sem saber diferenciar os irmãos (ASSIS, 2015a, p. 1178).

A cena da tragédia da morte de Flora no romance machadiano tem fortes ligações com a história do livro de Gênesis. No capítulo 27 o pai dos gêmeos bíblicos, Isaque, está à beira da morte e por isso chama o filho mais velho para dar a benção final. Aproveitando-se da cegueira do pai, Jacó se veste como seu irmão para confundir seu pai, o qual, na impossibilidade de diferenciar um do outro, dá a benção para o filho errado (Gn 27.18-24. In: Bíblia Sagrada, 1999).

Encontramos no penúltimo capítulo da obra Esaú e Jacó a morte da segunda mulher que era alvo do amor de ambos, sua mãe, Natividade. Ao passo que as últimas palavras de Flora apontavam para a confusão da semelhança entre os gêmeos através da pergunta "Ambos quais?", o último pedido de Natividade tinha relação com os conflitos existentes entre os filhos. Ela pede amizade entre eles: "Vocês vão ser amigos. Sua mãe padecerá no outro mundo, se os não vir amigos neste... Não quero outras saudades. Estas somente, a amizade verdadeira, e que se não quebre nunca mais. (ASSIS, 2015a, p. 1192)

A morte, "que arranca a pessoa ao pranto ou ao silêncio", se manifesta no romance na vida das duas mulheres amadas pelos gêmeos, Flora e Natividade. Ambas ligadas à questão da semelhança entre eles. A primeira, confusa, não conseguia separá-los; a segunda, moribunda, clamando para que se unissem.

De forma semelhante, tanto o romance machadiano, quanto a Bíblia, compartilham do tema do aspecto da gemelidade dos irmãos como promotor de confusão. Assim, uma trama antiga é renovada por Machado em um contexto moderno a partir do diálogo intertextual.

\section{Pedro e Paulo, Novo Testamento}

No Novo Testamento da Bíblia Sagrada encontra-se Pedro como um dos principais apóstolos chamados por Jesus, também chamado de Simão e Cefas (João 1:41-42 In: Bíblia Sagrada, 1999).

Pedro é conhecido como aquele que negou a Jesus diante da multidão 
(Mateus 26:58), porém, recebe o perdão de seu Senhor (João 21) e, após a ascensão de Cristo, torna-se um dos principais líderes da igreja cristã primitiva. No livro de Atos dos Apóstolos, ele surge como o principal orador entre os cristãos e toma a frene de diversos assuntos administrativos (Atos 2:14-41 In: Bíblia Sagrada, 1999).

Paulo de Tarso, chamado também de Saulo, antes de sua conversão ao cristianismo, surge no Novo Testamento como o perseguidor dos cristãos. Porém, após um acidente na estrada de Damasco, ele muda completamente de lado, e de perseguidor passa a perseguido, e de inimigo se torna um dos principais pregadores das doutrinas cristãs (Atos 7). Porém, a recepção de Paulo pelos cristãos não foi positiva. Muitos ainda o temiam como o perseguidor. Por causa da rejeição, Paulo decide pregar entre os gentios (termo usado para se referir àqueles que não faziam parte da linhagem judaica) e se torna o maior evangelista entre eles.

Os apóstolos Pedro e Paulo são retomados no romance machadiano para nomear os protagonistas da obra Esaú e Jacó. No capítulo VIII, intitulado Nem casal, nem general, é descrito o processo em que se deu a escolha dos nomes dos gêmeos a partir de um contexto religioso: um dia, estando Perpétua à missa, rezou o Credo, advertiu nas palavras: “... os santos apóstolos, S. Pedro e S. Paulo”, e mal pôde acabar a oração. Tinha descoberto os nomes; eram simples e gêmeos. Os pais concordaram com ela e a pendência acabou." (ASSIS, 2015a, p. 1058)

Machado deixa nítido que a origem dos nomes de seus protagonistas partiu das relações transtextuais de seu romance com a literatura católica, neste caso o Credo, que menciona o nome de S. Pedro e S. Paulo. Tal informação é confirmada mais à frente, quando, em um diálogo entre Santos e Plácido, este declarou acreditar que "os próprios espíritos de São Pedro e São Paulo houvessem escolhido aquela senhora para inspirar os nomes que estão no Credo; advirta que ela reza muitas vezes o Credo, mas foi naquela ocasião que se lembrou deles.” (ASSIS, 2015a, p. 1067)

Embora, no primeiro momento, a origem dos nomes seja atribuída diretamente ao Credo católico, mais à frente a Bíblia é apresentada como a fonte originária. No capítulo XV, no meio de um debate entre Santos e Plácido acerca dos nomes dos gêmeos,

O doutor foi à estante e tirou uma Bíblia, encadernada em couro, com grandes fechos de metal. Abriu a Epístola de São Paulo aos Gálatas, e leu a passagem do capítulo II, versículo 11, em que o apóstolo conta que, indo a Antioquia, 
onde estava São Pedro, "resistiu-lhe na cara". (ASSIS, 2015a, p. 1067)

O texto bíblico citado por Plácido se refere a um conflito entre Pedro e Paulo em decorrência do preconceito que havia entre judeus e gentios no início da igreja cristã. Em sua carta, dirigida aos Gálatas, Paulo expôs o problema explicando o desentendimento entre eles (Gálatas 2:11-14 In: Bíblia Sagrada, 1999).

A carta de Paulo revela o conflito que havia entre ele e Pedro. Embora ambos compartilhassem diversas semelhanças, como o apostolado, o espírito missionário dentro do cristianismo primitivo, eles se apresentam como rivais em questões políticas envolvendo a religião de seu tempo entre judeus e gentios. Este aspecto político certamente estava na mente de Machado ao relacionar os apóstolos com os gêmeos de seu romance, os quais, apesar de irmãos semelhantes, seriam opostos em diversas questões, inclusive a política.

No romance, diante da associação que Plácido fez entre os nomes de seus filhos com os personagens bíblicos, Santos, o pai dos meninos, fica extasiado.

Mistério engendra mistério. Havia mais de um elo íntimo, substancial, escondido, que ligava tudo. Briga, Pedro e Paulo, irmãos gêmeos, números gêmeos, tudo eram águas de mistério que eles agora rasgavam, nadando e bracejando com força. Santos foi mais ao fundo; não seriam os dois meninos os próprios espíritos de São Pedro e de São Paulo, que renasciam agora, e ele, pai dos dois apóstolos?... (ASSIS, 2015a, p. 1068)

Ao final da conversa com Aires, a Bíblia surge novamente nas entrelinhas do romance machadiano, só que desta vez o Antigo e o Novo Testamento se unem na figura dos gêmeos Esaú e Jacó. O narrador descreve Santos como quem "ia cheio de números da Escritura, de Pedro e Paulo, de Esaú e Jacó.” ?... (ASSIS, 2015a, p. 1068).

Se a partir dos personagens bíblicos Esaú e Jacó do Antigo Testamento, Machado ressalta a semelhança entre os irmãos, a partir das figuras de Pedro e Paulo, do Novo Testamento, o autor enfatiza a diferença existente entre os semelhantes. Sant'Anna, em sua obra Análise estrutural de romances brasileiros (1973) analisa o romance machadiano Esaú e Jacó e destaca os modelos sistemáticos de escrita dual utilizados pelo autor, enfatizando o aspecto de oposição presente ao logo do texto. Para exemplificar sua teoria, ele cita os trechos a seguir: 
"O que o berço dá só a cova o tira". (ASSIS, 2015a, p. 1065)

"A guerra é a mãe de todas as coisas". (ASSIS, 2015a, p. 1066)

"Na mulher o sexo corrige a banalidade; no homem agrava". (ASSIS, 2015a, p. 1087)

A oposição está presente na vida dos protagonistas do romance, Pedro e Paulo, que, apesar das semelhanças físicas, metaforizadas no fato de serem irmãos gêmeos, são rivais em diversas áreas de suas vidas. Ao mencionar as semelhanças físicas entre os meninos, o narrador as contrasta com as diferenças comportamentais. Ainda na primeira infância, quando muito pequenos, "Paulo era mais agressivo, Pedro mais dissimulado" (ASSIS, 2015a, p. 1070).

Ao crescerem os meninos, as diferenças se acentuaram. Quanto à profissão, Paulo tornou-se médico, ao passo que Pedro virou advogado. No campo político, Paulo defendia o partido republicano liberal; Pedro se tornou um monarquista conservador. A oposição entre a visão política dos dois surge em diversos momentos do romance. Uma delas emerge da data de aniversário dos gêmeos, ao passo que Paulo associava a data de seu nascimento à queda do trono de Pedro I, Pedro afirmava que nascera no "dia em que Sua Majestade subiu ao trono.” (ASSIS, 2015a, p. 1076) A preferência de cada irmão revelava a posição política entre eles. Ao passo que Pedro defendia a monarquia, Paulo comemorava o início da república.

A mãe surge no romance como a intermediadora entre ambos. Porém, sua solução é diferenciá-los e separá-los ainda mais: "Você será médico, disse Natividade a Pedro, e você advogado. Quero ver quem faz as melhores curas, e ganha as piores demandas." (ASSIS, 2015a, p. 1081) A estratégia da mãe, conforme revela o narrador, "Foi um recurso hábil separá-los; um ficava no Rio, estudando Medicina, outro ia para São Paulo, estudar Direito.” (ASSIS, 1904, p. 1081)

O papel da mãe como conciliadora surge desde que os meninos eram pequenos. No capítulo XVIII, intitulado De como vieram crescendo, o autor começa a traçar as diferenças de personalidade entre os irmãos. Para tanto, cita uma ocasião na qual, ao passearem pela rua, e receberem elogios quanto à beleza, cada um os tomava a seu favor, "neste último ponto divergiam, porque cada um deles tomava para si só as admirações.” (ASSIS, 2015a, p. 1048) Tentando minimizar os conflitos entre os filhos, a mãe intervém, 
argumentando: "Foi para ambos. Vocês são tão parecidos, que não podia ser senão para ambos.” (ASSIS, 2015a, p. 1071) A resposta da mãe não diminui o problema da oposição, antes, o aflora ainda mais. Como saber quem realmente estava sendo elogiado? A reação dos meninos demonstra tal rejeição: "Enfim, porque esta mandasse, abraçaram-se, mas foi um abraçar sem gosto, sem força, quase sem braços; encostaram-se um ao outro, estenderam as mãos às costas do irmão, e deixaram-nas cair.” (ASSIS, 2015a, p. 1071)

Que metáfora construída por Machado para representar a oposição entre os semelhantes! A cena descreve os gêmeos no conflito um com o outro no contexto da busca pela distinção de sua identidade. Machado amplia as diferenças para algo não somente externo. Segundo ele, "em verdade, qualquer outra viveria a tremer pela sorte dos filhos, uma vez que houvera a rixa anterior e interior." (ASSIS, 2015a, p. 1072)

As duas rixas, anterior e interior, fazem uma alusão à conexão que é feita na obra entre a luta dos meninos prevista desde o ventre da mãe. Esta luta vai perdurar durante toda a vida deles. Aqui então, novamente a questão da oposição conecta o romance machadiano à narrativa bíblica dos irmãos Esaú e Jacó, no qual, brigavam desde o ventre materno.

No último capítulo do livro, o pedido da mãe paira constantemente sobre a consciência de Pedro e Paulo, que na Câmara demonstraram uma união até então não vista. Eles “entravam juntos, andavam juntos, saíam juntos. Duas ou três vezes votaram juntos, com grande escândalo dos respectivos amigos políticos" (ASSIS, 2015a, p. 1192). Porém, a união durou apenas um ano. "Em maio seguinte, só Pedro lhe apareceu" na câmara. Diante do comportamento dos irmãos, os deputados afirmaram que pareciam "outros". Tal admiração leva a um diálogo final entre um deputado e Aires. O homem então pergunta: “- O senhor que se dá com eles diga-me o que é que os fez mudar, concluiu o amigo." Aires, o conselheiro, responde: "- Mudar? Não mudaram nada; são os mesmos." Para Aires, Pedro e Paulo "eram os mesmos, desde o útero". (ASSIS, 2015a, p. 1193).

A imagem do útero nos lembra tanto a semelhança entre os gêmeos, quanto o conflito entre ambos, assim temos nas últimas palavras da obra uma alusão intertextual que conecta o romance machadiano diretamente à narrativa bíblica de Gênesis de Esaú e Jacó.

\section{Considerações finais}

Como afirmamos na introdução, no presente artigo nos dedicamos a 
apresentar uma ferramenta que possibilitasse a identificação e análise dos textos bíblicos presentes em obras literárias, exemplificadas aqui nos textos machadianos. A partir deste processo inicial torna-se possível mergulhar em estudos sobre temas e ressignificações de textos bíblicos em obras literárias.

Há algumas possibilidades metodológicas de análise dos textos e, como demonstrado, uma abordagem metodológica baseia-se na teoria da transtextualidade de Gérard Genette (2010) o qual, em termos gerais, estudou os diálogos entre textos, denominados por ele de "relações transtextuais", as quais se referiam a tudo o que põe em relação, ainda que "secreta, um texto com outros e que inclui qualquer relação que vá além da unidade textual de análise. (GENETTE, 2010) A teoria da transtextualidade de Genette, em suas diferentes divisões, apesar de ter suas limitações, pode ser uma ferramenta útil para o estudante que deseja analisar o texto "antigo" da Bíblia escondido sob o "novo" olhar da literatura.

Neste trabalho apresentamos algumas obras de Machado de Assis, o qual demonstrou ser um conhecedor dos textos bíblicos, ao dialogar com diversos temas e personagens extraídos das páginas consideradas sagradas pelos cristãos. Porém, outros grandes autores fizeram o mesmo, com várias referências e abordagens dialogando com textos bíblicos como ocorre, por exemplo, na obra de Dostoievski, Os Irmãos Karamazov (2012).

Da mesma forma, em Machado de Assis, muitas obras dialogam com vários textos bíblicos que permitem analisar, sob diferentes ângulos, não apenas as referências à Bíblia, como também as provocações ao debate, presentes nestes livros, que demonstram a existência de diversas possibilidades de novos estudos sobre este e outros autores em diálogos com textos sagrados, tanto do cristianismo, quanto de outras grandes religiões existentes no planeta.

\section{Referências}

BÍBLIA Sagrada. Sociedade Bíblica do Brasil. Bíblia de Estudo Almeida Revista e Atualizada. 1999.

BRESSANE, Hugo. O aspecto religioso da obra de Machado de Assis. São Paulo: Edições Paulinas, 1978.

BRUM, Fernando Machado. Literatura e Religião: estudo de referências religiosas na obra de Machado de Assis. Dissertação de Mestrado. Programa de Pós-graduação em Letras da Universidade Federal do Rio Grande do Sul. Porto Alegre, 2009.

CALDWELL, Helen. O Otelo Brasileiro de Machado de Assis. São Paulo: Ateliê 
Editorial, 2008.

DAMASCENO, Elenito Saldanha. Paródia das palavras de Jesus nas crônicas de Machado de Assis. Nau Literária, Porto Alegre. v. 6. n. 1. p. 1-19. 2010.

DOSTOIEVSKI, F. Os irmãos Karamazov. 3. ed. São Paulo: Editora 34, 2012.

FERRAZ, S. As bem-aventuranças nas versões de Borges, de Machado de Assis, da Bíblia Satânica de Anton Lavey e na Versão para ao mestre com Carinho. Ipotesi, Juiz de Fora. v.16. n.2. p. 113-127. 2013.

FRANÇA, E. M.; VIEIRA, A. M. T. Ruptura ou amadurecimento?: uma análise dos primeiros contos de Machado de Assis. Recife: Editora da UFPE, 2008.

FRYE, Northrop. O Código dos códigos: a Bíblia e a literatura. São Paulo: Boitempo, 2004.

GASPARI, Silvana de; RAMOS, Diógenes Braga. Perspectivas teológicas e literárias do texto apócrifo: Apocalipse de Baruch. In: FERRAZ, S., et al. (orgs.) Deuses em poéticas: estudos de literatura e teologia [online]. Belém: UEPA; Campina Grande: EDUEPB, 2008. p. 352-364.

GEISLER, Norman; NIX, William. Introdução Bíblica: como a Bíblia chegou até nós. Editora Vida: São Paulo, 1997.

GENETTE, G. Palimpsestos: a literatura de segunda mão. Belo horizonte: Edições Viva Voz, 2010.

GOMES, E. Machado de Assis. Rio de janeiro: Livraria São José, 1958.

KOCH, I. G. V; BENTES, A. C.; CAVALCANTE, M. M.. Intertextualidade: diálogos possíveis. São Paulo: Cortez, 2012.

KRISTEVA, Júlia. Introdução à Seminálise. São Paulo: Debates, 1969.

MACHADO DE ASSIS, J. M. Obra completa. São Paulo: Editora Nova Aguilar, 2015a. Tomo I.

MACHADO DE ASSIS, J. M. Obra completa. São Paulo: Editora Nova Aguilar, 2015b. Tomo II.

MACHADO DE ASSIS, J. M. Obra completa. São Paulo: Editora Nova Aguilar, 2015c. Tomo III.

MAGALHÃES, A. C. de M. A Bíblia como obra literária: hermenêutica literária dos textos bíblicos em diálogo com a teologia. In: FERRAZ, S., et al. (Orgs). Deuses em poéticas: estudos de literatura e teologia. Belém: UEPA; Campina Grande: EDUEPB, 2008.

MATHEWS, K. A. The New American Commentary: Genesis. vol. 1A. Nashville: Broadman \& Holman Publishers, 1996.

MERQUIOR, J. G. De Anchieta a Euclides: breve história da literatura brasileira. São Paulo: É Realizações Editoras, 1996.

MORAES, E. V. de. A literatura como traição: os versos de Dante em O Alienista. 
Caminhos metodológicos de aproximação entre Bíblia e 203 literatura a partir de Gérard Genette em obras machadianas

Machado de Assis em linha, Rio de Janeiro. v. 6. n. 11. 2013. p. 39-61.

SANT'ANNA, Affonso Romano de. Análise Estrutural de Romances Brasileiros. Petrópolis, Vozes, 1973.

SCHWARZ, R. Ao vencedor as batatas. 3. edição. São Paulo: Duas Cidades, Editora 34, 2007.

SILVA, Glenda da. Machado de Assis, um leitor da Bíblia: análise do mito do duplo em Esaú e Jacó. Dissertação de Mestrado. Uberlândia: Programa de PósGraduação em Letras, 2015.

Submetido em: 26-5-2020

Aceito em: 26-11-2020 